\title{
Penerapan Sistem Pendukung Keputusan Dalam Menentukan e-Commerce Terbaik Dengan Menggunakan Metode SAW
}

\author{
Jenni Veronika Br Ginting \\ Prodi Teknik Informatika, STMIK Kristen Neumann, Medan, Indonesia \\ Email: veronikarossy11@gmail.com
}

\begin{abstract}
Abstrak-e-Commerce merupakan jual beli barang atau suatu produk secara online contohnya seperti seseorang konsumen mendatangi sebuah toko yang menjual segala hal yang kita butuhkan dalam kehidupan sehari-hari dan kita bisa mendapatkannya hanya dengan satu jari dalam sebuah aplikasi maupun situs web site resmi dengan adanya jaringan internet. tetapi dibalik kemudahan masih ada hal yang membuat seorang konsumen tidak mau melakukan tansaksi jual beli online dikarenakan masih banyak situs e-commerce yang membuat kecewa konsumen dalam melakukan transaksi online dari bentuk produk yang diterima tidak sebaik yang dipasarkan pada situs jual beli online tersebut, telat dalam perjanjian estimsi hari penerimaan barang dari ketentuan yang berlaku, dan respon penjual terhadap pembeli yang buruk, maka dari pada itu perlu dilakukan penerapan komputer untuk mendukung keputusan dalam penentuan e-commerce terbaik, agar konsumen dapat memilih situs e-commerce mana yang akan dikunjungi, metode Simple Additive Weighting (SAW) merupakan metode yang mudah dalam tahapan pencarian perangkingan dalam penentuan suatu keputusan berdassarkan sistem.
\end{abstract}

Kata kunci : e-Commerce, SPK, Simple Additive Weighting (SAW)

\begin{abstract}
Commerce is buying and selling goods or a product online for example like a consumer comes to a store that sells everything we need in everyday life and we can get it with just one finger in an application or on an official website with an internet network. but behind the convenience there are still things that make a consumer not want to do a transaction buying and selling online because there are still many e-commerce sites that make consumers disappointed in making online transactions from the form of products received are not as good as those marketed on these online buying and selling sites, late in agreement of estimation day of receipt of goods from the applicable provisions, and the seller's response to the buyer is $\mathrm{bad}$, therefore it is necessary to implement a computer to support the decision in determining the best e-commerce, so consumers can choose which e-commerce site to visit, the method Simple Additive Weighting (SAW) is an easy method in the ranking search stage in determining a decision based on the system.
\end{abstract}

Keywords: e-Commerce, DSS, Simple Additive Weighting (SAW)

\section{PENDAHULUAN}

Indonesia merupakan negara yang memiliki kepadatan penduduk no 4 terpadat di dunia dan Indonesia juga merupakan negara yang aktif dalam transaksi jual beli barang, pada era teknologi saat ini sangat banyak kemudahan yang kita temui dan kita dapatkan dari bantuan terknologi itu sendiri, teknologi juga saat ini banyak digunakan mulai dari membantu dalam memudahkan mendapatkan informasi dalam negeri maupun luar negeri, dalam alat transportasi, pendidikan, ilmu kedokteran dan kehidupan sehari-hari, bukan hanya itu saja kegiatan bisnis saat ini juga dilakukan dengan memanfaatkan teknologi itu sendiri, kegiatan transaksi jual beli barang maupun penyaluran jasa juga sudah menggunakan bantuan teknologi.

Masyarakat pada saat ini sangat ketergantungan dengan teknologi terutama dalam hal transaksi dimana masyarakat yang ingin menjual suatu produk yang mereka punya tidak perlu lagi harus mengeluarkan biaya yang sangat banyak untuk memasarkan produknya dan dengan adanya teknologi saat ini pencapaian pasar tidak hanya dalam ruang ingkup kecil, jangkauan pemasarannya sampai dengan seluruh wilayah Indonesia hingga manca negara, jual beli online itu sendiri disebut dengan e-Commerce dan sangat banyak jenis situs website eCommerce yang memudahkan masyarakat untuk membeli produk yang mereka inginkan dalam kehidupan sehari-harinya tanpa harus keluar rumah dan menita banyak waktu. ada banyak sistem e-Commerce yang terkemuka di Indonesia seperti Lazada, Shoope, Blibli, Toko pedia, Buka lapak, JD ID, olx, dan banyak lainnya.

Sistem e-Commerce memudahkan seseorang dalam bertransaksi online tetapi dibalik semua kemudahan yang didapatkan ada juga hal negatif yang timbul dari adanya e-commerce contohnya banyaknya masyarakat yang sudah membeli suatu produk tetapi ketika produk itu telah sampai ke tangan pembelinya justru produk tersebut malah tidak sesuai dengan keadaan yang tertera pada keterangan poduk mulai dari warna, ukuran, sampai estimasi hari yang sudah ditentukan tidak sesuai dengan keadaan. Dan sangat banyak e-Commerce berupa website jual beli online yang menyediakan produk dan barang yang sama dengan layanan dan kualitas yang berbeda sehingga membuat masyarakat masih bingung memilih salah satu e-Commerce manakah yang terbaik untuk meminimalisirkan rasa khawatir yang timbul dalam transaksi online, maka dari itu dibutuhkan sebuah Sistem Pendukung keputusan (SPK). SPK merupakan sistem berbasis komputer yang memberikan kemudahan dalam menghasilkan suatu keputusan yang sifatnya objektif dari beberapa alternatif dan kriteria yang saling berhubungan[1]-[3].

Dalam sistem pendukung keputusan ini penulis menggunakan metode Simple Additive Weighting (SAW) yang merupakan metode sederhana yang mampu menganalisa alternatif-alternatif yang ada untuk menghasilkan suatu keputusan dengan mudah[4]-[6]. Dibandingkan dengan metode sejenis, seperti MOORA[7]-[9], VIKOR[10]-[12]. 
Dari penjelasan diatas penulis tertarik mengadakan penelitian tentang pemilihan e-Commerce terbaik yang saat ini sedang berkembang, sehingga hasil penelitian dapat memberikan memudahkan bagi masyarakat untuk lebih selektif lagi dalam menentukan pilihan bertransaksi secara online.

\section{METODE PENELITIAN}

\section{1 e-Commerce}

Electronic commerce yaitu perniagaan barang maupun jasa yang dilakukan melalui elektonik, electronic commerce lebih biasa disebut dengan nama e-Commerce dan juga merupakan bagian dari e-business atau dalam keseharian di kenal dengan jual beli online.

\subsection{Sistem Pendukung Keputusan}

Sistem pendukung keputusan adalah suatu sistem komputerisasi yang interaktif dan terstruktur dan merupakan sistem yang bisa dikembangkan dan lebih berorientasi kepada perancangan masa depan yang tidak direncanakan priode waktu dalam penggunaannya[1], [3], [13]-[15].

\subsection{Simple Additive Weighting (SAW)}

Metode SAW merupakan metode untuk menetukan nilai yang sudah terbobot dengan mencari nilai dari penjumlahan terbobot dari semua alternative untuk semua Kriteria dan atribut[4], [16], [17].

\section{HASIL DAN PEMBAHASAN}

Dalam menentukan e-Commerce terbaik perlu diketahui dulu beberapa cara atau metode yang digunakan untuk mendapatkan dan menentukan keputusan yang terbaik dengan menggunakan beberapa kriteria yang saling berhubungan dan dapat membantu dalam menentukan hasil yang tepat dalam mendukung penentuan dalam pemilihan e-commerce terbaik, kriteria itu sendiri didapatkan dari orang-orang yang terbiasa meakukan transaksi online, Alternatif merupakan kandidat yang akan dipilih berdasar kan kriteria. Kriteria dan bobot merupakan hal yang harus dimiliki oleh setiap alternatif untuk menentukan e-commerce terbaik berdasarkan data yang sudah ada.

Tabel 1. Alternatif

\begin{tabular}{cc}
\hline Kode & Nama Alternatif \\
\hline A1 & Lazada \\
A2 & Toko Pedia \\
A3 & Blibli.com \\
A4 & Shopee \\
A5 & Buka Lapak \\
\hline
\end{tabular}

Tabel 2. Kriteria dan bobot e-Commerce Terbaik

\begin{tabular}{clcc}
\hline kriteria & \multicolumn{1}{c}{ Nama } & Keterangan & Bobot \\
\hline C1 & Kualitas Produk & Benefit & $35 \%$ \\
C2 & Estimasi Hari & Benefit & $25 \%$ \\
C3 & Pengunjung Situs e-commerce & Benefit & $20 \%$ \\
C4 & Respon Pelayanan & Benefit & $20 \%$ \\
\hline
\end{tabular}

Dari kriteria yang telah ditentukan berikut ini merupakan penjelasan dari setiap kriteria yang tertera pada penentuan e-commerce terbaik:

1. Kualitas Produk

Merupakan rata-rata yang didapat kan berdasarkan survey masyarakat yang terbiasa menggunakan berbagai jenis e-commerce, contohnya yaitu kesamaan produk yang diterima oleh custumer dengan keterangan yang disajikan dalam situs website e-commerce nya, kebanyakan dari pelanggan kecewa terhadap barang yang didapatkannya setelah membeli barang melalui online shop.

2. Estimasi Hari

Ketika barang telah dipesan oleh pembeli via online aka nada perjanjian hari bahwa produk akan tiba sesuai dengan perjanjian, tetapi ada juga beberapa dari pihak penjual sering melakukan keterlambatan yang membuat konsumen tidak percaya terhadap salah satu situs tersebut.

3. Pengunjung situs e-commerce

Semakin banyak yang mengunjungi salah satu situs e-commerce, makan akan semakin banyak jumlah masyarakat yang percaya dengan kualitas dan kuantitas yang di berikan oleh pihak salah satu perusahaan ecommerce tersebut.

4. Respon pelayanan 
Respon ini merupakan manajemen pemilih perusahaan atau situs e-commerce dalam memenuhi tanggung jawab terhadap barang yang akan diterima oleh pelanggan berupa claim jika terjadi hal yang tidak diinginkan ketika melakukan transaksi jual-beli Online.

Tabel 3. Data Alternatif dan Kriteria

\begin{tabular}{c|cccc}
\hline \multirow{2}{*}{ Alternative } & \multicolumn{4}{|c}{ Kriteria } \\
\cline { 2 - 5 } & Kualitas Produk & Estimasi Hari & $\begin{array}{c}\text { Pengunjung situs } \\
\text { e-commerce }\end{array}$ & $\begin{array}{c}\text { Respon } \\
\text { Pelayanan }\end{array}$ \\
\hline Lazada & Baik & Cukup baik & 26 juta & Baik \\
Toko Pedia & Sangat Baik & Sangat Baik & 66 juta & Baik \\
Blibli.com & Cukup Baik & Baik & 21,4 juta & Cukup Baik \\
Shopee & Sangat Baik & Sangat Baik & 56 juta & Cukup Baik \\
Buka Lapak & Baik & Baik & 42,9 juta & Baik \\
\hline
\end{tabular}

Dari data diatas maka dapat diperoleh angka menggunakan fuzzy untuk mendapatkan nilai dari penilaian berupa kata menjadi angka Mulai dari kata "sangat baik" diperoleh angka "5", "Baik" diperoleh angka "4", "cukup baik" diperoleh angka "3", "Buruk" diperoleh angka "2", "Sangat Buruk" diperoleh angka "1". Maka dari itu dapat data sebagai berikut:

Tabel 4 Nilai Alternatif

\begin{tabular}{ccccc}
\hline & C1 & C2 & C3 & C4 \\
\hline A1 & 4 & 3 & 28 & 4 \\
A2 & 5 & 4 & 66 & 4 \\
A3 & 3 & 5 & 21,4 & 3 \\
A4 & 5 & 5 & 56 & 3 \\
A5 & 4 & 4 & 42,9 & 4 \\
\hline
\end{tabular}

$\operatorname{Max}=5,5,66,4$

$\operatorname{Min}=3,3,21.4,3$

Langkah dalam pengerjaan pertama dengan cara tentukan terlebih dahulu nilai maksimal dan minimal setiap kolom untuk menentukan pengunakan rumus berdasarka nilai "cost" dan "Benefit", jika benefit maka nilai setiap kriteria dibagikan dengan nilai maksimal dari tiap kolom kriteria, jika sudah mendapatkan nilai keseluruhan maka dibuatkan matrix normalisasi, langkah ke dua dikalikan nilai yang didapatkan tadi dengan setiap bobot yang sudah ditentukan sebelumnya dan setiap kriteria yang sudah dikalikan dijumlahkan dengan kriteria lainnya berdasarkan perbaris, setelah itu urutkan nilai perangkingan berdasarkan dengan nilai tertinggi, berikut ini merupakan hasil dari nilai perangkingan dapat dilihat pada table berikut ini:

Tabel 5. Hasil Akhir

\begin{tabular}{ccc}
\hline alternatif & Nilai & Rank \\
\hline Lazada & 0,7336 & 5 \\
Toko Pedia & 0,95 & 1 \\
Blibli.com & 0,74 & 4 \\
Shopee & 0,9272 & 2 \\
Buka Lapak & 0,8375 & 3 \\
\hline
\end{tabular}

\section{KESIMPULAN}

Dari pembahasan di atas, penulis menyimpulkan bahwa Toko Pedia menduduki peringkat 1 terbaik, diikuti oleh Shopee, Buka Lapak, Blibli.com dan Lazada. Sistem berbasis pendukung keputusan dapat memberikan hasil akhir yang lebih objektif dibandingkan keputusan yang dibuat oleh pengambil keputusan. Penggunaan sistem pendukung keputusan mampu memberikan kemudahan kepada pengambil keputusan untuk menghasilkan suatu keputusan yang lebih baik. Hasil akhir dari penelitian dapat dijadikan dasar bagi masyarakat dalam melakukan pemilihan transaksi e-Commerce yang dilakukan secara online.

\section{REFERENCES}

[1] S. Kusumadewi, S. Hartati, A. Harjoko, and R. Wardoyo, Fuzzy Multi-Attribute Decision Making (Fuzzy MADM). Yogyakarta: Graha Ilmu, 2006.

[2] G.-H. Tzeng and J.-J. Huang, Multiple Attribute Decision Making Method And Applications. CRC Press, 2011.

[3] D. Nofriansyah and S. Defit, Multi Criteria Decision Making (MCDM) pada Sistem Pendukung Keputusan. 2018.

[4] S. H. Sahir, R. Rosmawati, and K. Minan, "Simple Additive Weighting Method to Determining Employee Salary Increase Rate," Int. J. Sci. Res. Sci. Technol., vol. 3, no. 8, pp. 42-48, 2017.

[5] R. T. Utami, D. Andreswari, and Y. Setiawan, "Implementasi Metode Simple Additive Weighting (SAW) dengan 
pembobotan Rank Order Centroid(ROC) Dalam Pengambilan Keputusan Untuk Seleksi Jasa Leasing Mobil,” J. Rekursif, vol. 4, no. 2, pp. 209-221, 2016.

[6] Y. M. Kristania, "Implementasi kombinasi metode ahp dan saw dalam pendukung keputusan penentuan kredit perumahan rakyat," J. Telemat., vol. 11, no. 1, pp. 65-78, 2018.

[7] J. Afriany, L. Ratna, S. Br, I. Julianty, and E. L. Nainggolan, "Penerapan MOORA Untuk Mendukung Efektifitas Keputusan Manajemen Dalam Penentuan Lokasi SPBU,” vol. 5, no. 2, pp. 161-166, 2018.

[8] D. Assrani, N. Huda, R. Sidabutar, I. Saputra, and O. K. Sulaiman, "Penentuan Penerima Bantuan Siswa Miskin Menerapkan Metode Multi Objective Optimization on The Basis of Ratio Analysis (MOORA)," Penentuan Penerima Bantu. Siswa Miskin Menerapkan Metod. Multi Object. Optim. Basis Ratio Anal., vol. 5, no. 2407-389X (Media Cetak), pp. 1-5, 2018.

[9] Mesran, R. K. Hondro, M. Syahrizal, A. P. U. Siahaan, R. Rahim, and Suginam, "Student Admission Assessment using Multi-Objective Optimization on the Basis of Ratio Analysis (MOORA)," J. Online Jar. COT POLIPT, vol. 10, no. 7, pp. 1-6, 2017.

[10] Y. J. B. Parrangan et al., "The implementation of VIKOR method to improve the effectiveness of Sidi learning graduation," Int. J. Eng. Technol., vol. 7, no. 3.4 Special Issue 4, 2018.

[11] M. Mesran et al., "The VIKOR Method to Support the Effectiveness of Decisions in Determining Work Incentive Recipients," J. Phys. Conf. Ser., vol. 1175, p. 012043, 2019.

[12] I. Wijaya, "Penerapan Metode AHP dan VIKOR Dalam Pemilihan Karyawan Berprestasi," pp. 301-309, 2019.

[13] Kusrini, Konsep dan Aplikasi Sistem Pendukung Keputusan. 2007.

[14] D. Nofriansyah, Konsep Data Mining Vs Sistem Pendukung Keputusan. 2015.

[15] T.-P. Turban, E., Aronson, J., \& Liang, Decision Support Systems And Inteligence System. US: Prentice-Hall, 2005.

[16] T. widodo Nuri Guntur Perdana, "Sistem Pendukung Keputusan Pemberian Beasiswa Kepada Peserta Didik Baru Menggunakan Metode TOPSIS," in Semantik, 2013, vol. 2013, no. November, pp. 1-8.

[17] Khairul;, M. Simaremare, A. Putera, and U. Siahaan, "Decision Support System in Selecting The Appropriate Laptop Using Simple Additive Weighting," Int. J. Recent TRENDS Eng. Res., vol. 2, no. 12, pp. 215-222, 2016. 